\title{
Mastitis Detection in Holstein Sahiwal Crossbred Cattle (Bos taurus) Using Different Brands and Dilution Levels of Liquid Anionic Surfactants
}

\author{
Yancy Ogdamin Waminal ${ }^{2 *}$, Marjorie Raboy Gambol ${ }^{1}$, Ahron Caiman Sabado ${ }^{1}$, John Paul Muring Vallejos ${ }^{1}$, \\ Ronaldo Curameng Briones ${ }^{2}$ and Esteward Jones Manlangit Estabillo ${ }^{2}$ \\ ${ }^{1}$ Undergraduate Student, Department of Animal Science, College of Agriculture and Forestry, Tarlac Agricultural \\ University, Tarlac, Central Luzon, Philippines \\ 2Department of Animal Science, College of Agriculture and Forestry, Tarlac Agricultural University, Tarlac, Central Luzon, \\ Philippines \\ *Corresponding author email: waminal0830@gmail.com
}

\begin{abstract}
The study was conducted to evaluate the effect, consistency, and economic viability of using different brands and dilution levels of liquid anionic surfactants to detect Mastitis in dairy cattle. Fifty-five milk samples were collected and subjected to macroscopic evaluation at a cattle farm located in Sta. Maria, Bulacan, Philippines. Milk samples were brought to the Philippine Carabao Center National Headquarters and Genepool Science City of Muñoz, Nueva Ecija for Somatic Cell Count. The experiment used 10 treatments with 3 replications arranged in a Completely Randomized Design. The macroscopic evaluation results showed that liquid anionic surfactants at 30\%-50\% dilution levels could detect Mastitis in dairy cattle. This was validated by the somatic cell count results from PCC Dairy Laboratory. On the other hand, statistical analysis results revealed that the treatments and the control (commercial mastitis test) were comparable except for brand $Z$ at a $40 \%$ dilution rate. Brand $Z$ at $30 \%$ and $50 \%$ dilution rate were found to be consistent among other treatments in detecting Mastitis in dairy cattle. In terms of economic viability, brand $X$ and brand $Y$ at $30 \%$ were the cheapest and had the lowest production cost and highest percentage savings.
\end{abstract}

Keywords: liquid anionic surfactant, mastitis, milk sample, dairy cattle, somatic cell count

\section{Introduction}

Milk is considered a complete food being secreted by female mammals to nourish their young. Several problems can occur in this gland, and the most common is mastitis. Mastitis is a common disease in mammals including dairy livestock industry, which is very detrimental since it decreases the quantity and quality of milk production (Syamsi et al., 2019).

Mastitis is a prevalent disease that affect the mammary gland causing inflammation that is painful to dairy animals and reduces milk quality. Poor management practices or environmental micro-organisms cause the disease. The dairy industry paid more attention to subclinical and clinical Mastitis because of its negative effect on the animal and dairy farms' economic status worldwide. Through early detection of Mastitis, treatments can be employed immediately to reduce the infection and the transmission to other cows.
Although commercial mastitis tests are available, their use in the Philippines are limited. These test kits are expensive and not accessible to some dairy farmers. Moreover, local farmers are not trained of conducting mastitis test for milk. It is necessary to find a material that has the same effect but is able to accommodate the ease of application in farmers.

Given that liquid anionic surfactant does not require expensive solutions, instruments, and technical laboratory skills, it is also accessible; hence, it is efficient to detect mastitis infection in the shortest possible time. Despite improvements made in animal production and health, particularly in prevention by early detection of contagious disease and therapeutic medicine, this study was conducted to determine the efficacy of liquid anionic surfactant as a reagent for mastitis test. 


\section{Materials and Methods}

\section{Scope and Delimitation of the Study}

This study was conducted from January to May 2020. Milk samples were collected at a dairy cattle farm located in Sta. Maria, Bulacan. Milk samples were brought to the Philippine Carabao Center National Genepool Headquarters, Science City of Muñoz, Nueva Ecija for Somatic Cell Count. The study was limited to mastitis detection in dairy cattle using different brands and dilution levels of liquid anionic surfactants.

\section{Experimental Design}

A total of 55 milk samples from dairy cattle were used in this study. The experiment was laid out following the Completely Randomized Design (CRD). Treatment with a corresponding dilution level was replicated three (3) times. The 3-day sample collection represented the three (3) replications.

There were ten treatments used in the study as shown in Table 1.

Table 1. Brands and dilution levels of liquid anionic surfactants used in the study

\begin{tabular}{cc}
\hline Treatments & $\begin{array}{c}\text { Brands and dilution levels of liquid } \\
\text { anionic surfactants }\end{array}$ \\
\hline 1 & commercial mastitis test (Control) \\
2 & $30 \%$ Brand $X+70 \%$ Distilled water \\
3 & $40 \%$ Brand $X+60 \%$ Distilled water \\
4 & $50 \%$ Brand $X+50 \%$ Distilled water \\
5 & $30 \%$ Brand $Y+70 \%$ Distilled water \\
6 & $40 \%$ Brand $Y+60 \%$ Distilled water \\
7 & $50 \%$ Brand $Y+50 \%$ Distilled water \\
8 & $30 \%$ Brand $Z+70 \%$ Distilled water \\
9 & $40 \%$ Brand $Z+60 \%$ Distilled water \\
10 & $50 \%$ Brand $Z+50 \%$ Distilled water \\
\hline
\end{tabular}

\section{Preparation of the Test Solution}

All the necessary equipment used were thoroughly cleaned, disinfected, and air-dried to prevent contamination of milk samples.

\section{Commercial Mastitis Test and Liquid Anionic}

\section{Surfactant Test Solution Preparation}

On the preparation of the Commercial Mastitis Test Solution, the diluting distilled water was first tested by using 1-2 drops of reagent concentrate. The second step was mixing $10 \%$ of reagent and $90 \%$ water and was stirred gently in a beaker to avoid bubbles. Lastly, the mixture was transferred in the empty bottles and appropriately labeled.

Liquid Anionic Surfactant Test Solution preparation was similar to that of the commercial solution. To make a $500 \mathrm{ml}$ test solution, different percentage of brands of liquid anionic surfactants and distilled water was computed to the desired volume of the test solution. The distilled water's computed amount volume was measured for the different dilution levels using a beaker, then measured the computed amount volume of liquid anionic surfactant and added into the prepared water solution. The mixture was stirred gently to avoid the excessive formation of bubbles. Lastly, the solution was carefully transferred into clean empty container bottles and labeled. The same procedure was employed following the treatments specified in the experiment.

\section{Mastitis Testing Using Different Test Solutions}

Mastitis testing on commercial reagent and Liquid Anionic Surfactant had the same procedure. It was done strictly using the following procedures. First, raw milk was collected and placed in a bottle. Five $\mathrm{ml}$ of milk from each quarter was placed into the commercial reagent paddle with four compartments labeled as A, B, C, and D. Second, an equal amount of commercial reagent and LAS solution with different brands and dilution levels was added to each quarter in the paddle. Then, the paddle was rotated in a circular motion to mix the milk and the solution thoroughly. Visible reaction disintegrated after about 20 seconds. The reaction was scored visually according to the gel formation: the more gel formation, the higher the score. Results were recorded accurately per animal and per teat. 
Collection of Milk Samples for Somatic Cell Count

Before milk collection, 60 pieces of the centrifuge tube, permanent marker, ball pen, record book, and ice chest were prepared. The procedure of collection was done following the protocol of the dairy laboratory. Strictly $50 \mathrm{ml}$ of milk was drawn from four quarters of the udder into the centrifuge tube. The tubes were labeled with the cow number and teat location and immediately store in the ice chest. The cow number, calving date, milk yield per day, and the result of the commercial reagent test for each quarter were recorded in the sheet provided by the Philippine Carabao Center dairy laboratory.

\section{Laboratory Analysis}

Milk samples were collected from the four quarters of the udder from each experimental animal and subjected to macroscopic evaluation.

Table 2. Guide to macroscopic evaluation

\begin{tabular}{|c|c|c|c|c|}
\hline No & $\begin{array}{l}\text { Result } \\
\text { Symbol }\end{array}$ & Meaning & Description & Remarks \\
\hline 1 & - & Negative & Free from the gelatinous formation & Negative of Mastitis \\
\hline 2 & -+ & Trace & $\begin{array}{l}\text { Slight thickening of the mixture. Trace } \\
\text { reaction seems to disappear with a } \\
\text { continuous rotation of the paddle. If all } \\
\text { four quarters read trace, there is no } \\
\text { infection. If one or two quarters read } \\
\text { trace, infections are possible. }\end{array}$ & $\begin{array}{l}\text { Possible Mastitis } \\
\text { Infection }\end{array}$ \\
\hline 3 & + & Weak Positive & $\begin{array}{l}\text { A distinct precipitate formed, and milk } \\
\text { become slightly viscous, but no tendency } \\
\text { of gel formation }\end{array}$ & $\begin{array}{l}\text { Sub-clinical Infection } \\
\text { (Grade } 1 \text { Mastitis) }\end{array}$ \\
\hline 4 & ++ & $\begin{array}{l}\text { Distinct } \\
\text { Positive }\end{array}$ & $\begin{array}{l}\text { The mixture thickens immediately with } \\
\text { some gelatinous formation formed. }\end{array}$ & $\begin{array}{l}\text { Serious Mastitis } \\
\text { Infection } \\
\text { (Grade } 2 \text { Mastitis) }\end{array}$ \\
\hline 5 & +++ & $\begin{array}{l}\text { Strong } \\
\text { Positive }\end{array}$ & $\begin{array}{l}\text { A gelatinous formation will be formed and } \\
\text { causes the mixture's surface to become } \\
\text { convex, and a thick mass is formed in the } \\
\text { middle of the paddle while doing swirling } \\
\text { and titling. When the mixture is poured } \\
\text { out, the whole mass formation will drop } \\
\text { without leaving any remains or if there is a } \\
\text { presence of little sticky mixture will be left } \\
\text { but will drop also }\end{array}$ & $\begin{array}{l}\text { Serious Mastitis } \\
\text { Infection } \\
\text { (Grade } 3 \text { Mastitis) }\end{array}$ \\
\hline
\end{tabular}

Note: Formation of gel involves the binding of leukocytes due to the anionic of the liquid antibacterial detergent on the milk. Gelatinous formation usually indicates the quarter of the cow's udder is positive or infected with Mastitis. Source: McCurnin's Clinical Textbook for Veterinary Technicians

Table 3. Somatic cell range and interpretation

\begin{tabular}{lll}
\hline $\begin{array}{l}\text { Test result } \\
\text { Cmt code }\end{array}$ & $\begin{array}{l}\text { Equivalent somatic cell range } \\
\text { (cells/ml) }\end{array}$ & \multicolumn{1}{c}{ Interpretation } \\
\hline$(-)$ Negative & $0-200,000$ & Healthy Udder \\
\hline$(-+)$ Trace & $>200,000-400,000$ & $\begin{array}{l}\text { Sub-clinical Infection. If all four } \\
\text { quarters read trace, there is no } \\
\text { infection. If one or two quarters } \\
\text { read trace, infections are possible. }\end{array}$ \\
\hline $\begin{array}{l}(+) \text { Grade 1 weak positive } \\
\text { (++) Grade 2 distinct positive }\end{array}$ & $400,000-1,200,000$ & Sub-clinical Infection \\
\hline$(+++)$ Grade 3 strong positive & Over 5,000,000 & Serious Mastitis Infection \\
\hline
\end{tabular}

Source: Philippine Carabao Center, National Gene Pool Headquarters - Dairy Laboratory, Science City of Muñoz, Nueva Ecija. 
Milk samples were graded the guides in Table 2 . Milk samples were also submitted immediately to the Philippine Carabao Center National Gene Pool Headquarters - Dairy Laboratory, Science City of Muñoz, Nueva Ecija, Philippines for Somatic Cell Count Analysis using Cytometry. Based on their recommendations, milk samples were declared infected with mastitis or not using Table 3 as guide.

\section{Data Gathered}

The following data were gathered:

1. Macroscopic Evaluation Results are tabulations in Mastitis Detection using the Commercial reagent and different brands of liquid anionic surfactants.

2. Somatic Cell Count Results are results of the milk samples collected from the different quarters of the udder of experimental animals that was conducted by PCC.

3. Cost of Producing Liquid Anionic Surfactant Agent is the computed expenses of producing test solutions.

\section{Data Analysis}

All the data gathered were statistically analyzed using the Analysis of Variance (ANOVA) for Completely Randomized Design (CRD). The mean of the results was compared employing the Least Significant Difference test at a 0.01 level of confidence.

\section{Results and Discussion}

\section{Mastitis Detection by Macroscopic Evaluation}

Results of the macroscopic evaluation for milk samples using commercial mastitis test and different Brands of Liquid Anionic Surfactants (LAS) at different dilution rates are presented in Table 4.

Table 4 shows that Brands $\mathrm{X}, \mathrm{Y}$, and $\mathrm{Z}$ at $30 \%-50 \%$ dilution rate were able to detect different levels of positive Mastitis like CMT. Brand $Z$ at $30 \%$ and $50 \%$ dilution level has the highest ability to detect mastitis at its highest grade, i.e., grade 2 .

The ability of the LAS to detect mastitis was due to its anionic surface-acting agent akylanylsulfonate - an active ingredient found in surfactants that have the same action in the deoxyribonucleic acid (DNA) reagent which dissolves or disrupts the outer cell wall and the nuclear cell wall of any leukocyte, which are primarily fat. DNA is released from the nuclei. DNA will get together to form a stringy mass. As the number of leukocytes increases, the amount of gel formation also increases linearly.

This is parallel to the result of the study conducted by Gangan et al. (2018) wherein liquid anionic surfactants can be used to detect clinical and subclinical mastitis in dairy animals.

\section{Effectiveness of Liquid Anionic Surfactants at Different Dilution Levels}

Presented in Table 5 is the comparison among the different treatments which includes the different brands and dilution levels of liquid anionic surfactants.

Analysis of variance revealed that all treatments have no significant difference to the commercial mastitis test except for treatment 9 (Brand $Z$ at a $40 \%$ dilution rate).

This is parallel to the result of the study by Gangan et al. (2018) wherein liquid anionic surfactants produced comparable result to commercially available mastitis test reagents.

\section{Consistency of Using Liquid Anionic Surfactants in Mastitis Detection}

Results on macroscopic evaluation reveal that the different liquid anionic surfactants and dilution levels were consistently able to detect mastitis dairy cattle's fresh milk. Statistical analysis of variance in Table 4 also reveals the consistency of the liquid anionic surfactants at $30 \%-50 \%$ dilution rate to commercial mastitis test except treatment 9 (brand $Z$ at $40 \%$ dilution rate). 
Table 4. Results of the macroscopic evaluation using CMT and different brands and dilution levels of liquid anionic surfactants

\begin{tabular}{cccccc}
\hline \multirow{2}{*}{ Treatments } & Negative & Trace & Grade 1 & Grade 2 & Grade 3 \\
\cline { 2 - 6 } & 35 & 15 & 5 & 0 & 0 \\
Treatment 1 & 33 & 18 & 4 & 0 & 0 \\
Treatment 2 & 31 & 19 & 5 & 0 & 0 \\
Treatment 3 & 30 & 20 & 5 & 0 & 0 \\
Treatment 4 & 29 & 21 & 5 & 0 & 0 \\
Treatment 5 & 31 & 19 & 5 & 0 & 0 \\
Treatment 6 & 29 & 21 & 5 & 0 & 0 \\
Treatment 7 & 28 & 23 & 3 & 1 & 0 \\
Treatment 8 & 18 & 35 & 2 & 0 & 0 \\
Treatment 9 & 28 & 22 & 4 & 1 & 0 \\
Treatment 10 & 28 & & & \\
\hline
\end{tabular}

Table 5. Mean grade for mastitis detection using the CMT 5-point hedonic scale

\begin{tabular}{ccc}
\hline Treatments & Treatment id & Means \\
\hline 1 & Commercial mastitis test & $1.46^{\mathrm{a}}$ \\
2 & Brand $\mathrm{x}$ at 30\% dilution rate & $1.40^{\mathrm{a}}$ \\
3 & Brand $\mathrm{x}$ at $40 \%$ dilution rate & $1.46^{\mathrm{a}}$ \\
4 & Brand $\mathrm{x}$ at 50\% dilution rate & $1.49^{\mathrm{a}}$ \\
5 & Brand y at 30\% dilution rate & $1.48^{\mathrm{a}}$ \\
6 & Brand y at 40\% dilution rate & $1.48^{\mathrm{a}}$ \\
7 & Brand y at a 50\% dilution rate & $1.50^{\mathrm{a}}$ \\
8 & Brand z at a 30\% dilution rate & $1.50^{\mathrm{a}}$ \\
9 & Brand z at a 40\% dilution rate & $1.68^{\mathrm{b}}$ \\
10 & Brand $\mathrm{z}$ at a 50\% dilution rate & $1.50^{\mathrm{a}}$ \\
\hline
\end{tabular}

Note: Means followed by the same letter are not significantly different at a $1 \%$ level of significance. $\mathrm{P}(>\mathrm{F})=0.0005$. CV (\%) $=3.39$

Table 6. Cost efficiency of using different brands of liquid anionic surfactants (LAS) at different dilution levels

\begin{tabular}{lcccc}
\hline $\begin{array}{c}\text { Brand and } \\
\text { Dilution rate }\end{array}$ & $\begin{array}{c}\text { Cost per } \\
\text { gallon }(\nexists)\end{array}$ & $\begin{array}{c}\text { Cost of CMT/LAS } \\
\text { Per } 5 \mathrm{ml}(\nexists)\end{array}$ & $\begin{array}{c}\text { Savings from the } \\
\text { use of LAS }(\nexists)\end{array}$ & $\begin{array}{c}\text { Percentage of savings } \\
\text { from the use of LAS (\%) }\end{array}$ \\
\hline Commercial reagent & 1,136 & 1.42 & & \\
Brand $X$ at 30\% & 268 & 0.335 & 1.085 & 323.88 \\
Brand $X$ at $40 \%$ & 344 & 0.43 & 0.99 & 230.23 \\
Brand $X$ at $50 \%$ & 420 & 0.525 & 0.895 & 170.48 \\
Brand $Y$ at 30\% & 268 & 0.335 & 1.085 & 323.88 \\
Brand $Y$ at $40 \%$ & 344 & 0.43 & 0.99 & 230.23 \\
Brand $Y$ at 50\% & 420 & 0.525 & 0.895 & 170.48 \\
Brand $Z$ at 30\% & 304 & 0.38 & 1.04 & 273.68 \\
Brand $Z$ at $40 \%$ & 392 & 0.49 & 0.93 & 189.80 \\
Brand $Z$ at 50\% & 480 & 0.6 & 0.82 & 136.67 \\
\hline
\end{tabular}

Therefore, all the treatments were consistent in mastitis detection but treatments 8 and 10 (Brand $\mathrm{Z}$ at $30 \%$ and $50 \%$ dilution rate) were found to be the most consistent among all treatments. This was confirmed by the Somatic Cell Count result (Appendix B) and antibacterial component of the brand can kill bacteria. This result confirms De Guzman et al. (2019) that
$30 \%$ and $50 \%$ of brand $Z$ were also consistent in detecting mastitis.

\section{Economic Viability}

Presented in Table 6 is the economic viability of using different brands and dilution level of liquid anionic surfactants in detecting subclinical and clinical mastitis in dairy cattle. 
Table 6 showed that brand $X$ and brand $Y$ at $30 \%$ dilution level obtained the lowest cost per gallon ( $\ngtr$ 268) and cost per sample ( $₹$ 0.335) among all treatments including commercial reagent. In terms of the amount saved using LAS and percentage savings from using commercial reagent, brand $X$ and brand $Y$ at $30 \%$ dilution level acquired the highest savings and percentage savings among all treatments with 1.085 and $323.88 \%$.

Similarly, Dela Cruz et al. (2019) stated that using liquid anionic surfactants in detecting Mastitis ruminants was viable because of its availability in the nationwide market and has cheaper cost compared to commercial reagent

\section{Conclusions}

Based on the results of the study, the researchers concluded that Brand $Z$ at $30 \%$ and $50 \%$ dilution levels is the most consistent surfactant solution in detecting mastitis on fresh dairy cattle milk, while Brands $X$ and $Y$ at $30 \%$ dilution level are the cheapest solutions to use.

\section{References}

Andersen, HJ, LH Petersen, FM Aarestrup, and M Chriel. 2003. Evaluation of the surveillance program of Streptococcus agalactiae in Danish dairy herds. Journal of Dairy Science. 86 (4): 1233-1239

Andersen, S, IR Dohoo, RO Riekerink, and H Stryhn. 2011. Diagnosing intramammary infections: evaluation of definitions based on a single milk sample. Journal of Dairy Science. 94:250-291.

Breen, JE, AJ Bradley, and MJ Green. 2009. Quarter and cow risk factor associated with somatic cell count greater than per milliliter in United Kingdom dairy cows. Journal of Dairy Science. 92 (7): 3106-3115.

Bytyqi, H, U Zaugg, K Sherifi, A Hamidi, M Gjonbalaj, S Muji, and $\mathrm{H}$ Mehmeti. 2011. Influence of management and physiological factors on somatic cell count in raw milk in Kosova. Veterinarski Archiv, 80(2):173-183.

Cervinkowa, D, H Vlokova, I Borodacouva, and J Makouvoca. 2013. Prevalence of mastitis pathogens in milk from clinically healthy cows. Veterinary Medicine Journal. 58 (11):567-575.
Cunha, RP, LR Molina, AM Carvalho, and RM Ferreira. 2008. Sub-clinical mastitis and relationship between somatic cell count with a number of lactations, production, and chemical composition of milk. Vet Med. 60:19-24.

Dingwell, RT, KE Leslie, YH Schukken, JM Sargeant, and LL Timms. 2003. Evaluation of the California mastitis test to detect an intramammary infection with a major pathogen in early lactation dairy cows. Canadian Veterinary Journal. 44: 413.

Dobranie, V, B Njari, B Miokovic, and R Resanova. 2008. The influence of the season on chemical composition and somatic cell count of bulk tank cow's milk. Vet Archive. 78.235-242

El-Attar, AA, ME Salama, and MM Abd El-Samie. 2002. Incidence of mastitis in lactating cows and buffaloes kept under different management conditions in Ismailia province. Veterinary Medicine Journal. 2: 583.

Gangan, JA. 2018. Detection of Mastitis in dairy buffalo using different brands and dilution levels of liquid anionic surfactants.

Halasa, T, and O Osterus. 2007. Economic effects of bovine mastitis and mastitis management. Vet $Q$. 29:18-31.

Kandasamy, S, BB Green, AL Benjamin, and DE Kerr. 2011. Cow variation in dermal fibrilast response to lipopolysaccharide reflected in resolution of inflammation during $E$. coli mastitis. Journal of Dairy Science. (94(12):5963-75 doi: 103168 / jds 20111-4288.

Kuang, Y, H Jia, K Miyanaga, and Y Tanji. 2009. Effect of milk on antibacterial activity of tetracycline against Escherichia coli and Staphylococcus aureus isolated from bovine. Applied microbiology and biotechnology. 84. 135-42.

Leslie, KE, RT Dingwell, and LL Tiims. 2002. Evaluation of the California mastitis test to detect an intramammary infection with a major pathogen in early lactation dairy cows. The Canadian Veterinary Journal. 44(5): 413-416.

Le Roux, Y, and F Moussaqui. 2003. Polymorphonuclear protolyse acting and milk composition change. Vet res. 629-645.

Ma, Y, C Ryan, DM Barbano, DM Gakton, MA Rudan, and KJ Boor. 2000. Effect of somatic cell count on quality and shelf-life of pasteurized fluid milk. Journal of Dairy Science. 83:264-274.

Mahmoud, AA. 1988. Some studies on subclinical mastitis dairy cattle. Assiut Veterinary Medicine Journal. 20: 150.

Ogola, H, and A Shitandi. 2007. Effect of mastitis on raw milk composition quality. Journal of Dairy Science. 8:237-242.

Rady, AA, and M Sayed. 2009. Epidemiological studies on subclinical mastitis in dairy cows in 
Assiut governorate. Veterinary World. 2(10):373380.

Santos, MV, and DM Barbaro. 2003. Effect of somatic cell count on proteolyses and lipolysis in pasteurized fluid milk during shelf-life storage. Journal of Dairy Science. 86:2491-2503.

Seegers, H, C Flouricho, and F Beaudu. 2003. Related to mastitis economics in dairy cattle herds. Veterinary Research. 34:475-91.

Schukken, YH, DJ Wilson, F Welcome, LG Tikofsky, and RN Gonzalez. 2003. Monitoring udder health and milk quality using somatic cell counts. Veterinary Research. 34:579-596.

Sharma, N, NK Singh, and MS Bhadwal. 2011. Relationship of somatic cell count and mastitis: An overview. Division of Veterinary Clinical Medicine and Jurisprudence, SKUAST-J, India. Asian-Australian Journal of Animal Science. 24(3): 429-438.

Syamsi, AN, M Pratiwi, and AP Nugroho. 2019. Inhibition Activity of Garlic (Allium sativum) Skin
Extract on Mastitis Causing Microorganism. Animal Production, 21(1):38-42.

Viguier, C, S Arora, N Gilmartin, K Welbeck, and R O'kennedy. 2009. Mastitis detection: current trends and future perspectives. Trends in Biotechnology. 27. 486-493.

Waminal, YO. 2021. Low-cost liquid anionic surfactant in mastitis detection for small scale dairy buffalo raisers in the Philippines. European Journal of Agricultural and Rural Education. 2(4), 43-48.

Waminal, YO, GASP Tubalinal, and CN Mingala. 2019. Molecular characterization of lactoferrin gene as genetic marker to subclinical mastitis in water buffaloes (Bubalus bubalis). Asian Journal of Agriculture and Biology. 7(4):564-572.

Zdunczyk, S, H Zerbe, and M Hoedemaker. 2003. Importance of oestrogen and oestrogen-active compounds for udder health in cattle: A review. Dtsch Tierarztl Wochenschr. 110: 461. 